\title{
Relationship between Sleep Quality and the Percentage of Body Fat in Children (Ages 9-12 Years) in the Public Elementary School of IKIP I Makassar City
}

\author{
Septiyanti Septiyanti, Yusriani Yusriani* \\ Department of Public Health, Faculty of Public Health, Universitas Muslim Indonesia, Makassar, Indonesia
}

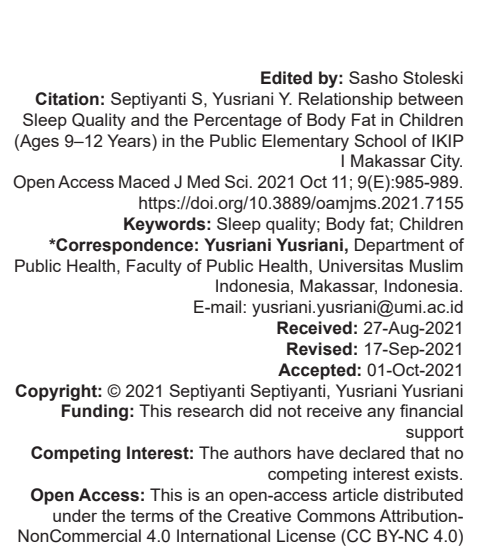

Abstract

AIM: This study aimed to determine the relationship of sleep quality with the percentage of body fat in children (ages 9-12 years) in the Elementary School Complex of IKIP I Makassar.

METHODS: The study used the Analytical Survey design with a cross-sectional approach. The researcher will compare the causes and consequences variables simultaneously and explain the relationship between the research variables through hypothesis testing. This study uses quantitative methods, namely through assessing sleep quality and body fat percentage using a questionnaire. The data was collected through in-depth interviews and observations of children. Sampling uses purposive sampling and data analysis using the Chi-Square test.

RESULTS: There was no significant relationship between sleep quality and body fat percentage. However, after being tested based on the components of sleep quality, it was seen that good sleep quality and poor sleep quality in component 3 (sleep duration). Moreover, component 4 (daily sleep efficiency) had a significant relationship between sleep duration and daily sleep efficiency with body fat percentage.

CONCLUSION: There is a significant relationship between sleep duration and daily sleep efficiency with the percentage of body fat in SD Negeri IKIP I Makassar. Recommendations from this research are needed on the relationship between sleep quality and student achievement index

\section{Introduction}

Sleep is a vital biological process related to human physiology, neurology, and other physiological systems [1]. Sleep activity is an essential need for humans, especially children. Sleep is a risk factor that has been reported to increase the incidence of overweight and obesity. Meta-analysis studies provide evidence that short sleep duration is significant with an increased risk of obesity in children. Sleep duration is also potentially necessary to prevent overweight and obesity among children [2]. Research in Australia shows that the prevalence of obesity in children aged 5-12 years who have sleep time $<10 \mathrm{~h}$ is $22.3 \%$. Short sleep duration $(<10 \mathrm{~h})$ was found to be associated with an increased risk of obesity 2.61 times greater than in children whose sleep duration $\geq 10 \mathrm{~h}$ [3]. Meta-analysis research by Matricciani et al. nearly 700,000 children, with data from 20 countries for more than 100 years, found that children currently sleep 20-25 min less per day on average than their parents at their age. Lack of sleep is associated with several adverse health outcomes in children [4].

Several studies have reported an association between short sleep duration and health problems, including associations with mortality, type 2 diabetes, hypertension, metabolic syndrome, respiratory disease, obesity in children and adults, and poor personal health [2]. The average nightly duration of sleep reported for school-age children was $9.4 \mathrm{~h}$, which is not yet what is recommended [5]. Seputra et al. showed that the prevalence of sleep disorders in obese children was $66.7 \%$ [6]. Sleep disturbances in children impact the lack of physical activity followed by an increase in calorie intake, which is a risk factor for overweight and obesity.

Short sleep duration can increase hunger, increase the chance to eat, change thermoregulation, and increase fatigue. Increased hunger and increased opportunity to eat increase energy intake, whereas changes in thermoregulation and increased fatigue decrease energy expenditure. An increase in energy intake that is not matched by energy expenditure can lead to obesity [7]. Lack of sleep (2-4 h a day) can result in an $18 \%$ loss of leptin and a $28 \%$ increase in ghrelin, leading to a $23-24 \%$ increase in appetite. Leptin is a protein hormone produced by fat tissue that controls fat reserves and affects appetite, while ghrelin is a hormone that can affect hunger and satiety. If leptin decreases and ghrelin increases, it can increase hunger and make metabolism slow down and reduce the ability to burn fat in the body [7]. 
School-age children 6-13 years of sleep need 9-11 $\mathrm{h}$ of sleep, consisting of 8-9 $\mathrm{h}$ of sleep at night and $2 \mathrm{~h}$ during the day. However, it is not appropriate than the recommended ones to be more interested and spending time on cellphones, games, computers, TV, electronic media, the internet, and caffeine products. All of which can cause sleeplessness, nightmares, and disturbances in their sleep [4]. Around 50 million girls and 74 million boys are overweight and obese in the world [8]. The prevalence of obesity increased by almost $40 \%$ in Indonesia from 2000 to 2013 [9]. The percentage of obesity in Indonesia among school children is increasing, in 2013 based on the highest $\mathrm{BMI} / \mathrm{U}$ category in children aged $5-12$ years at $18.8 \%$, $13-15$ years at $10.8 \%$, and $16-18$ years $7.3 \%$. The percentage of obesity in South Sulawesi Province based on the BMI/U category of children aged 5-12 years was 2.3\% in 2013 and increased in 2017 by $4.0 \%$ [10], [11].

The IKIP I Makassar State Elementary School, which is located in Makassar, South Sulawesi, is one of the leading elementary schools in Makassar City. Most children who go to school have parents who work as teachers, lecturers, and entrepreneurs - the economic income of the students' parents in middle and upperincome. Secondary data in each class are obtained from the homeroom teacher that, on average, each class has $18 \%$ overweight children and $5 \%$ obesity [12]. Children who are overweight are 4 times more likely to become obese as adults [13]. Childhood overweight is a strong predictor of obesity and other metabolic risk factors in adulthood. The chance of developing various chronic diseases include cardiovascular disease, type 2 diabetes, hypertension, dyslipidemia, osteoarthritis, some types of cancer, and obstructive sleep apnea [14]. An unhealthy lifestyle, including sedentary activity, screen time, unhealthy diet, low levels of physical activity, and inadequate sleep quality, can contribute to the risk of obesity [15].

Children who are overweight cause metabolism in the body to below. That is due to the formation of energy that takes longer due to breaking down food sources into slow glycogen, so that much fat is stored in the body [16]. The excess body associated with cardiovascular risk factors. The measure of body fat is accurate in assessing and determining the relationship between adiposity and mortality [17]. If the body composition is well known, it will make it easier for further actions to maintain health, so a measurement that can distinguish between fat mass and non-fat mass is needed. The body composition assessment is a method that can determine the fat mass and non-fat mass that make up the weight [18]. Nowadays, many use ordinary weight meters to indicate body weight, whereas ordinary weight meters cannot distinguish between fat mass and non-fat mass.

In this regard, this research needs to study the relationship between sleep quality and the percentage of body fat in children (ages 9-12 years) at the Public Elementary School Kompleks IKIP I Makassar.

\section{Methods}

The type of research used is an analytical survey with a cross-sectional study design, namely, a study where data collection is carried out simultaneously. Research studies the relationship between the independent variable (sleep quality) and the dependent variable (body fat percentage of elementary school students). The population in this study were all students and classes IV and V of the State Elementary School of IKIP I Makassar, totaling 157 students. According to the inclusion and exclusion criteria, the sample was some of the fourth and fifth-grade students-number of samples 68. Research ethics were obtained from the ethics committee of Universitas Muslim Indonesia.

This research begins with preparations, among others, to survey to obtain information on the number of students in SDN Kompleks IKIP I Makassar. Then the sampling was carried out using purposive sampling. After the preparations were complete, it was continued with interviews with students at SDN Kompleks IKIP I Makassar regarding sleep quality with the percentage of body fat students at SDN Kompleks IKIP I Makassar, Makassar City. Furthermore, the data collected are then processed and analyzed with the help of computers, then presented in tables and narratives.

\section{Results}

Table 1 shows the type of respondent's age. Most of them are 9-10 years old at 75\%, Pocket Money

Table 1: General characteristics of samples at SD IKIP 1 Makassar

\begin{tabular}{|c|c|c|c|c|c|c|}
\hline \multirow[t]{3}{*}{ Characteristics } & \multicolumn{4}{|c|}{ Sleep Quality } & \multirow{2}{*}{\multicolumn{2}{|c|}{ Total }} \\
\hline & \multicolumn{2}{|c|}{ Good } & \multicolumn{2}{|c|}{ Poor } & & \\
\hline & $\mathrm{n}$ & $\%$ & $n$ & $\%$ & $\mathrm{n}$ & $\%$ \\
\hline \multicolumn{7}{|l|}{ Grade } \\
\hline IV & 12 & 17.6 & 16 & 23.5 & 28 & 41.2 \\
\hline $\mathrm{V}$ & 10 & 14.7 & 30 & 44.1 & 40 & 58.8 \\
\hline \multicolumn{7}{|l|}{ Sex } \\
\hline Male & 8 & 11.8 & 26 & 38.2 & 34 & 50.0 \\
\hline Female & 14 & 20.6 & 20 & 29.4 & 34 & 50.0 \\
\hline \multicolumn{7}{|l|}{ Age } \\
\hline $9-10$ years & 15 & 22.1 & 36 & 52.9 & 51 & 75.0 \\
\hline $11-12$ years & 7 & 10.3 & 10 & 14.7 & 17 & 25.0 \\
\hline \multicolumn{7}{|c|}{ Pocket money (Rupiah) } \\
\hline$<5.000$ & 2 & 2.9 & 4 & 5.9 & 6 & 8.8 \\
\hline 5.000 & 19 & 27.9 & 28 & 41.2 & 47 & 69.1 \\
\hline 15.000 & & & & & & \\
\hline$>15.000$ & 1 & 1.5 & 14 & 20.6 & 15 & 22.1 \\
\hline \multicolumn{7}{|c|}{ Frequency of exercise } \\
\hline Every day & 16 & 8.8 & 18 & 26.5 & 24 & 35.3 \\
\hline One A week & 15 & 22.1 & 27 & 39.7 & 42 & 61.8 \\
\hline $\begin{array}{l}\text { One A } \\
\text { month }\end{array}$ & 1 & 1.5 & 1 & 1.5 & 2 & 2.9 \\
\hline Total & 22 & 32.3 & 46 & 67.6 & 68 & 100 \\
\hline
\end{tabular}


(Rupiah) students are $5000-15,000$ at $69.1 \%$, and frequency of exercise is One A Week by $61.8 \%$, and sleep quality including poor, namely, $67.6 \%$.

Table 2 shows that of the 68 samples. Good sleep quality and poor sleep quality were dominated by 11 samples $(50 \%)$ and 22 samples $(47.8 \%)$ who had a body fat percentage in the healthy category. It is based on the analysis with the Chi-square Statistical test shows the value of $p=0.198(p>0.05)$ which means that there was no significant relationship between sleep quality and the percentage of body fat of the children at SD Nigeria IKIP I Makassar.

Table 2: Analysis of the relationship between sleep quality and body fat percentage

\begin{tabular}{|c|c|c|c|c|c|c|c|c|}
\hline \multirow[t]{3}{*}{ Sleep quality } & \multicolumn{6}{|c|}{ Body fat percentage } & \multirow[t]{3}{*}{ Total } & \multirow[t]{3}{*}{$\mathrm{p}$ value } \\
\hline & \multicolumn{2}{|c|}{ Under fat } & \multicolumn{2}{|c|}{ Healthy } & \multicolumn{2}{|c|}{ Over fat } & & \\
\hline & $\mathrm{n}$ & $\%$ & $\mathrm{n}$ & $\%$ & $\mathrm{n}$ & $\%$ & & \\
\hline Good & 10 & 45.5 & 11 & 50 & 1 & 4.5 & 22 & 0.198 \\
\hline Poor & 13 & 28.3 & 22 & 47.8 & 11 & 23.9 & 46 & \\
\hline Total & 23 & 33.8 & 33 & 48.5 & 12 & 17.7 & 68 & \\
\hline
\end{tabular}

Table 3 shows that sleep quality is good and sleep quality is poor in component 3 (sleep duration). Furthermore, the results of the Chi-square analysis for component 4 (daily sleep efficiency) is $p=0.009$ and. $p=0.001$. There was a significant relationship between sleep duration and daily sleep efficiency with the percentage of body fat of the students' SD Nigeria IKIP I Makassar

Table 3: Analysis of the relationship between components of sleep quality and body fat percentage

\begin{tabular}{|c|c|c|c|c|c|c|c|c|c|}
\hline \multirow[t]{3}{*}{ Sleep quality } & \multicolumn{6}{|c|}{ Body fat percentage } & \multirow{2}{*}{\multicolumn{2}{|c|}{ Total }} & \multirow[t]{3}{*}{ p value } \\
\hline & \multicolumn{2}{|c|}{ Under fat } & \multicolumn{2}{|c|}{ Healthy } & \multicolumn{2}{|c|}{ Overfat } & & & \\
\hline & $\mathrm{n}$ & $\%$ & $\mathrm{n}$ & $\%$ & $\mathrm{n}$ & $\%$ & $\mathrm{n}$ & $\%$ & \\
\hline \multicolumn{10}{|c|}{ Sleep quality is subjective } \\
\hline Good & 21 & 31 & 30 & 44 & 10 & 14.7 & 61 & 89.7 & \multirow[t]{2}{*}{0.485} \\
\hline Poor & 2 & 2,9 & 3 & 4.4 & 2 & 2.9 & 7 & 10.2 & \\
\hline \multicolumn{10}{|l|}{ Sleep latency } \\
\hline Good & 16 & 24 & 15 & 22 & 6 & 8.8 & 37 & 54.8 & \multirow[t]{2}{*}{0.187} \\
\hline Poor & 7 & 10 & 18 & 27 & 6 & 8.9 & 31 & 45.9 & \\
\hline \multicolumn{10}{|l|}{ Sleep duration } \\
\hline Good & 22 & 32 & 26 & 38 & 7 & 10.3 & 55 & 80.3 & \multirow{2}{*}{0.009} \\
\hline Poor & 1 & 1,5 & 7 & 10 & 5 & 7.3 & 13 & 18.8 & \\
\hline \multicolumn{10}{|c|}{ Daily sleep efficiency } \\
\hline Good & 22 & 32 & 30 & 44 & 8 & 11.8 & 60 & 87.8 & \multirow[t]{2}{*}{0.001} \\
\hline Poor & 1 & 1.5 & 3 & 4.4 & 4 & 5.9 & 8 & 11.8 & \\
\hline \multicolumn{10}{|c|}{ Sleep disorders } \\
\hline Good & 13 & 19 & 22 & 32 & 7 & 10.3 & 42 & 61.3 & \multirow[t]{2}{*}{0.84} \\
\hline Poor & 10 & 4.7 & 11 & 16 & 5 & 7.3 & 26 & 28 & \\
\hline \multicolumn{10}{|l|}{ Sleeping pills } \\
\hline Use & 22 & 32 & 32 & 47 & 12 & 17.7 & 66 & 96.7 & \multirow[t]{2}{*}{0.914} \\
\hline Non-use & 1 & 1,5 & 1 & 1.4 & 0 & 0 & 2 & 2.9 & \\
\hline \multicolumn{10}{|c|}{ Daytime activity dysfunction } \\
\hline Good & 10 & 15 & 9 & 13 & 2 & 2.9 & 21 & 30.9 & \multirow[t]{2}{*}{0.281} \\
\hline Poor & 13 & 19 & 24 & 35 & 10 & 14.7 & 47 & 68.7 & \\
\hline
\end{tabular}

\section{Discussion}

This research has been conducted at SD IKIP 1 Makassar involving 68 people. The results are shown in Table 1. The sample that has a poor sleep quality category is mostly in Class $V$ as 30 samples $(44.1 \%)$ male gender as many as 26 samples $(38.2 \%)$ aged 9-10 years, namely, 36 samples $(52.9 \%)$ were given an allowance of $5.000-15.000$ as many as 28 samples
$(41.2 \%)$ and only exercised every week as many as 27 samples $(39.7 \%)$. Sleep quality is a score obtained from a sample that has answered questions on the Pittsburgh sleep quality index which consists of 7 (seven) components. Each component has a value range of $0-3(0=$ indicating very good, $1=$ indicating good; 2 = indicating poorly; 3 = indicating very bad).

The results showed that from 68 samples. The percentage of poor sleep quality was 46 samples $(67.6 \%)$. Primarily found in the dysfunction component of daytime activities as many as 47 samples (69.1\%). Daytime activity dysfunction namely all forms of activity or work done during the day, and does not take breaks to nourish the body. Meanwhile, the percentage of good sleep quality was 22 samples (32.4\%). This study found that sleep quality in the bad category was more than the good quality of sleep. Sleep quality assessment includes several aspects such as subjective sleep quality, sleep latency, sleep duration, daily sleep efficiency, sleep disturbances, use of sleep medications, and daytime activity dysfunction [19].

Several aspects of sleep quality assessment revealed that subjective sleep quality was as many as seven samples (10.3\%). subjective sleep quality, namely, a description of the habit of sleeping at night. Sleep fatigue was 31 samples (45.6\%). Sleep fatigue is the duration from going to sleep to falling asleep. Someone with good sleep quality spends $<15 \mathrm{~min}$ to enter the next stage of sleep entirely. Sleep duration was 13 samples $(19.1 \%)$. Sleep duration was the average length of sleep per $24 \mathrm{~h} /$ day. Daily sleep efficiency as many as eight samples (11.8\%). Daily sleep efficiency namely a description of sleeping at night, the habit of getting out of bed in the morning, and the duration of sleep.

Sleep disorders in 26 samples (38.3\%), sleep disorders are disorders that can cause problems in sleep patterns either because they cannot fall asleep frequent waking at night. or the inability to go back to sleep. The use of sleeping pills is two samples $(3 \%)$ sleeping pills where a person is affected by a sleep disorder that causes difficulty sleeping. the solution or choice of people. in general. is to take sleeping pills - daytime activity dysfunction in 47 samples (69.1\%). According to Potter et al. (2014), several factors affect sleep quality one of which is a lifestyle [20]. Changes in children's lifestyles can cause a decrease in sleep quality. such as spending much time on cellphones watching television or using the internet. Based on Istiqomah and Lisiswanti's (2017) research. one monitor screen exposure $\geq 2 \mathrm{~h}$ per day can cause sleep disturbances [21]. The exposure factor of the monitor screen is in line with the general characteristics of the sample with 27 samples of TV ownership in the room (39.7\%). 37 samples $(54.4 \%)$ have a habit of playing cellphones $(54.4 \%)$. Most of the samples have personal cellphones as many as 45 samples $(66.2 \%)$ supported by the activity of the sample doing sports only every week as many as 27 samples $(39.7 \%)$. 
According to the National Sleep Foundation environmental factors can also increase and decrease sleep quality [22]. The presence of external stimuli can hinder sleep efforts such as uncomfortable temperatures and poor ventilation. A good temperature to provide good sleep quality is around $24-26^{\circ} \mathrm{C}$ [23]. Electronic media can adversely affect sleep quality, for example computer screens cellphones and televisions. Use at the wrong time and the brightness of the light emitted can cause changes in sleep patterns. Light emitted by electronic media to the retina will provide a signal to the hypothalamus and interfere with melatonin production in the body thereby changing the quality of sleep [24]. While the data for the sleeping environment sample in Table 2 show 12 samples (17.6\%). who like a bright light sleeping environment and two people $(2.9 \%)$ who like the sleeping environment with a warm temperature.

Other factors according to Wang et al. are namely that acute physical exercise can make sleep more soundly, increase the amount of sleep time and reduce waking during sleep [25]. Research conducted by Patel and $\mathrm{Hu}$ concluded that reduced sleep quality will also result in hormonal changes, namely losing $18 \%$ of leptin and increasing $28 \%$ of ghrelin which can cause an increase in appetite by 23-24\% [7]. Increased hormone ghrelin levels during sleep deprivation lead to increased fat production and increased intake of foods high in fat and carbohydrates. Poor sleep quality will contribute to chronic diseases such as heart disease, Diabetes mellitus, hypertension, stroke, depression, cognitive impairment, decreased quality of life, and accidents [2]

Then there is an increase in excessive food intake in children, resulting in the speed of formation of new fat cells which increases each year. And the greater the ability to store fat causes overweight and obesity. The process of breaking down food sources into glycogen is slow so that much fat is stored in the body [16]. The chi-square test results found no correlation between the incidence of body mass index on good and bad sleep quality with a $p>0.05(p=0.109)$. Cheng and Sekartini also reported similar results: there was no significant relationship between nutritional status and sleep quality in children aged 5-7 years in Kampung Melayu. East Jakarta [26]. In contrast to research conducted by Seputra et al. there is a significant difference in sleep quality between obese and non-obese children with a significant level of $0.00<0.05$ [27].

Body fat percentage is the total body fat mass, representing the total body fat storage expressed as a percentage (\%). The results of cross-tabulation analysis with the Chi-square statistical test found no relationship between the incidence of body fat percentage on good and bad sleep quality with $p>0.05$ ( $p=0.198$ ). Different research results by Al-Otaibi show that poor sleep quality has a high risk of high body fat percentage with a correlation coefficient of $p=0.025$ [28].

\section{Conclusion}

However, the results of the Chi-square test on sleep duration and daily sleep efficiency show that there is a significant relationship between sleep duration and daily sleep efficiency with the percentage of body fat in SD Nigeria IKIP I Makassar.

\section{References}

1. Al-Tannir MA, Kobrosly SY, Al-Badr AH, Salloum NA, Altannir YM, Sakkijha HM. Characterizing sleeping habits and disturbances among Saudi adults. Saudi Med J. 2016;37(12):1372-80. http// doi.org/10.15537/smj.2016.12.17373

PMid:27874154

2. Wu Y, Gong Q, Zou Z, Li H, Zhang X. Short sleep duration and obesity among children: A systematic review and meta-analysis of prospective studies. Obes Res Clin Pract. 2017;11(2):140-50. PMid:27269366

3. Morrissey B, Malakellis M, Whelan J, Millar L, Swinburn B, Allender $\mathrm{S}$, et al. Sleep duration and risk of obesity among a sample of Victorian school children. BMC Public Health. 2016;16(1):245. http//doi.org/10.1186/s12889-016-2913-4 PMid:26961765

4. Matricciani L, Olds T, Petkov J. In search of lost sleep: Secular trends in the sleep time of school-aged children and adolescents. Sleep Med Rev. 2012;16(3):203-11. http//doi.org/10.1016/j. smrv.2011.03.005

PMid:21612957

5. Anshory J, Tanziha I, Mappaompo A, Nasrah NM. The effect of physical activity (endurance and strength) and sleep management on BMI and body fat children overweight in Makassar city. Indian J Public Health Res Dev. 2018;9(10):417.

6. Seputra DP, Windiani IG, Adnyana IG. Prevalence of sleep disorders in obese children. E-J Med Udayana. 2017;6(4):125-29.

7. Patel SR, Hu FB. Short sleep duration and weight gain: A systematic review. Obesity. 2008;16(3):643-53. http//doi. org/10.1038/oby.2007.118 PMid:18239586

8. World Health Organization. Tenfold Increase in Childhood and Adolescent Obesity in Four Decades: New Study by Imperial College London and WHO. Geneva: World Health Organization; 2017. Available from: https://www.who.int/news/item/11-102017-tenfold-increase-in-childhood-and-adolescent-obesity-infour-decades-new-study-by-imperial-college-london-and-who [Last accessed on 2021 Aug 27].

9. Helble M, Francisco K. The Imminent Obesity Crisis in Asia and the Pacific: First cost Estimates; 2017.

10. RI BK. Hasil Utama RISKESDAS 2018; 2018.

11. Kementerian Kesehatan RI. Buku Saku Pemantauan Status Gizi. Buku Saku Pemantauan Status Gizi Tahun 2017. Kementerian Kesehatan RI; 2018. p. 7-11.

12. Anggraeni A. Hubungan Pola Konsumsi Makanan Jajanan dengan Status Gizi dan Kadar Kolesterol pada Anak SD Negeri IKIP I Makassar Tahun 2014. Universitas Islam Negeri Alauddin Makassar; 2014.

13. Cunningham SA, Kramer MR, Narayan KM. Incidence of childhood obesity in the United States. N Engl J Med. 2014;370:403-11. 
14. Piepoli MF, Hoes AW, Agewall S, Albus C, Brotons C, Catapano AL, et al. Guidelines: Editor's choice: 2016 European Guidelines on cardiovascular disease prevention in clinical practice: The sixth joint task force of the European society of cardiology and other societies on cardiovascular disease prevention in clinical practice (constituted by representatives of 10 societies and by invited experts) developed with the special contribution of the European Association for cardiovascular prevention and rehabilitation (EACPR). Eur Heart J. 2016;37(29):2315-81.

PMid:27222591

15. Ling J, Robbins LB, Wen F. Interventions to prevent and manage overweight or obesity in preschool children: A systematic review. Int J Nurs Stud. 2016;53:270-89. http//doi.org/10.1016/j. ijnurstu.2015.10.017 PMid:26582470

16. Permana H. Komplikasi Kronik dan Penyakit Penyerta Pada Diabetes. Bandung: Hasan Sadikin Hospital; 2009.

17. Schmid SM, Hallschmid M, Jauch-Chara K, Born JA Schultes B. A single night of sleep deprivation increases ghrelin levels and feelings of hunger in normal-weight healthy men. J Sleep Res. 2008;17(3):331-4. http//doi. org/10.1111/j.1365-2869.2008.00662.x

PMid:18564298

18. Ryu BR, Jeong H, Ryu HG. Bioelectrical impedance analysis by multiple frequencies for health care refrigerator. PIERS Online. 2010;6(7):640-5

19. Buysse DJ, Reynolds CF $3^{\text {rd }}$, Monk TH, Berman SR, Kupfer DJ. The Pittsburgh Sleep Quality Index: A new instrument for psychiatric practice and research. Psychiatry Res. 1989;28(2):193-213.

20. Potter PA, Perry AG, Stockert PA, Hall A. Essentials for Nursing Practice-E-Book. Amsterdam, Netherlands: Elsevier Health Sciences; 2014.
21. Istiqomah SN, Lisiswanti R. The impact of screen exposure on sleep disturbances and obesity rates in children. J Majority. 2017;6(2):73-8

22. Swanson LM, Arnedt JT, Rosekind MR, Belenky G Balkin TJ, Drake C. Sleep disorders and work performance: Findings from the 2008 national sleep foundation sleep in America poll. J Sleep Res. 2011;20(3):487-94. http//doi. org/10.1111/j.1365-2869.2010.00890.x PMid:20887396

23. Kim CR, Chun MH, Han EY. Effects of hypnotics on sleep patterns and functional recovery of patients with subacute stroke. Am J Phys Med Rehabil. 2010;89(4):315-22. http//doi. org/10.1097/PHM.0b013e3181c9fc5e PMid:20068430

24. Mesquita G, Reimão R. Quality of sleep among university students: Effects of nighttime computer and television use. Arq Neuro Psiquiatr. 2010;68(5):720-5. http//doi.org/10.1590/ s0004-282x2010000500009

PMid:21049182

25. Wang C, Chung S, Jin H, Zhang Y. Metabolic equivalent play an important role between exercise and sleep. In: Sleep Amer Acad Sleep Medicine one Westbrook Corporate CTR, STE 920, Westchester; 2012. p. A57.

26. Cheng W, Sekartini R. Hubungan Status Gizi, Asupan Besi, dan Magnesium dengan Gangguan Tidur Anak Usia 5-7 Tahun di Kampung Melayu, Jakarta Timur Tahun 2012. eJ Kedok Indones. 2014;2014:4012. http//doi.org/10.23886/ ejki.2.4012.

27. Anis S. Hubungan Komponen Kualitas Kehidupan Kerja (Quality of Work Life) Dengan Motivasi Kerja Pegawai Non Medis di Rumah Sakit Umum Daerah Pasar Rebo; 2015.

28. AL-Otaibi HH. Associations between sleep quality and different measures of obesity in Saudi adults. Glob J Health Sci. 2017;9(1):1-9. 